\title{
PEMBEKALAN PELATIHAN KERJA DALAM MENUMBUHKAN MINAT USAHA BAGI NARAPIDANA DI LAPAS
}

\author{
Maharidho Deel Ziko ${ }^{1}$, Ali Muhammad ${ }^{2}$ \\ ${ }^{12}$ Politeknik Ilmu Pemasyarakatan \\ Depok, Indonesia \\ ziko123gh@gmail.com¹, alimuhammad32@gmail.com²
}

\begin{abstract}
The increase in criminal activities occurring in the community has led to an increase in the population of the Institute (LAPAS). The government, as the policymaker in this case, advises prisoners so prisoners do not commit crimes again and are motivated. Work The purpose of this study was to analyze the effect of entrepreneurship training and work motivation on entrepreneurial interest in prisons. Data collection techniques with literature, observation and interviews. The program observed by researchers is an entrepreneurship education program in the form of skills training and direct communication. The tool used for data collection is the interview form. The results of this study indicate that there is a significant impact of entrepreneurship training and $100 \%$ motivation on entrepreneurial interest. This means that entrepreneurship training and better motivation for this Work are carried out by inmates, entrepreneurial interest will increase and vice versa.
\end{abstract}

Keyword: Entrepreneurship Training, Work Motivation, Interest In Entrepreneurship

\section{PENDAHULUAN}

Upaya pelatihan oleh Lapas kepada narapidana dilakukan agar mampu kembali menjadi warga masyarakat yang berguna dan tidak melanggar hukum kembali atau residivis. Hal itu dilakukan dengan memberikan pendidikan dalam bentuk pelatihan berwirausaha sebagai bekal pada saat keluar penjara untuk dilakukan penelitian dengan tujuan untuk mengetahui upaya pengelolaan pelatihan yang dilakukan pembina dalam menunmbuhkan jiwa berwirausaha narapidan melalui pelatihan di Lapas Kelas IIB Pariaman.

Secara harfiah, pengertian wirausaha adalah orang yang membuat suatu produk, menentukan cara produksi, menyusun operasi untuk mengadakan produk baru hingga mengatur permodalan serta pemasarannya. Menurut Kasmir, wirausaha merupakan seseorang yang mempunyai keberanian dalam mengambil risiko dari sebuah peluang usaha yang ada dengan harapan ia mampu mendapat sebuah pelajaran baru dari peluang yang ia ambil tersebut. Pada zaman sekarang minat masyarakat terhadap kewirausahaan tergolong rendah padahal peluang untuk mendapatkan pekerjaan sangat besar. Badan Pusat Statistik (BPS) melaporkan jumlah pengangguran di Indonesia ada sebanyak 
9,1 juta orang per Agustus 2021. Sedangkan menurut data kementerian koperasi pada bulan maret 2021, jumlah UMKM atau usaha mikro, kecil, dan menengah mencapai 64 juta. Itu sebenarnya perbandingan yang cukup besar dan mempunyai peluang kerja yang juga besar. Bisa kita lihat sebenarnya faktor kurangnya kemampuan atau keinginan dari diri seseorang untuk mencari pekerjaan. Kemudian pendidikan yang rendah juga menyebabkan orang tidak memiliki kesempatan untuk Bekerja karena kehilangan daya saing Kebutuhan ekonomi yang tinggi, pekerjaan yang terbatas, pengangguran yang tinggi menyebabkan tindakan menyimpang. Misalnya, kelompok sosial tingkat bawah memiliki Lebih sedikit peluang dibandingkan dengan kelompok masyarakat tingkat tinggi. Situasi muncul karena peluang dan fasilitas yang tidak merata, termasuk perbedaan dalam struktur peluang. Akibatnya, orang menjadi depresi, kecewa, dan dialihkan. Meningkatnya persaingan dalam pencarian kerja menyebabkan pengangguran yang lebih tinggi karena jumlah pencari kerja yang menganggur berdasarkan jumlah pekerjaan yang tersedia. Pengangguran adalah munculnya masalah sosial, yang mana Ada lebih banyak kasus kriminal. Pemerintah, sebagai pembuat kebijakan, dalam hal ini memberikan saran kepada penghuni penjara agar narapidana tidak lagi mengulangi tindak pidana. Pelatihan Kewirausahaan merupakan program yang sering berfokus pada pengembangan pengetahuan dan keterampilan dalam menyiapkan bisnis. Ini memperkenalkan peserta untuk melatih wirausaha dalam pengembangan bisnis, mampu merencanakan proyek, kegiatan bisnis.

Pelatihan ini merupakan alternatif atau cara alternatif yang dapat membentuk pola pikir kita yang digunakan sesuai dengan standar wirausaha, kemudian setelah pelatihan kita akan lebih siap dalam hal mental, mental dan finansial juga mampu bersaing di pasar bisnis. Pelatihan kewirausahaan memainkan peran penting dalam pengembangan energi. Inovasi dan kreativitas akan menghasilkan kepuasan serta kemakmuran, selain itu juga dapat mengurangi jumlah pengangguran, menciptakan lebih banyak lapangan kerja, mengurangi kemiskinan yang terjadi akibat krisis ekonomi hingga mengurangi kejahatan. Terungkap bahwa wirausahawan tidak dilahirkan - mereka berkembang menjadi roh wirausaha, bukan bakat lahir. Namun dengan potensi yang sedang berkembang didalam kehidupan sehariharinya, setelah itu baru pelajari ilmu wirausaha bagaimana cara menjadi wirausaha yang sukses. 
Pengusaha dikembangkan melalui semangat kewirausahaan, kemampuan untuk mengambil risiko, kemampuan dalam membaca peluang. Status kewirausahaan merupakan suatu proses dinamis dalam melihat, mengubah, dan menciptakan. Hal ini juga membutuhkan aplikasi energi dan hasrat untuk menciptakan serta membawa ide baru dan juga solusi yang kreatif. Hal penting termasuk juga kesediaan dalam mengambil risiko, termasuk juga waktu, modal dan pekerjaan. Keterampilan untuk mengumpulkan sumber daya yang diperlukan merupakan keterampilan mendasar guna membangun bisnis yang lebih terencana dengan baik. Sehingga akhirnya sebuah visi untuk menerima peluang yang dilihat orang lain menjadi kekacauan, konflik, dan juga menjadi kebingungan.

Motivasi yang tinggi memang harus ada pada orang yang ingin menjadi pengusaha yang sukses dikarenakan apabila memiliki motivasi yang tinggi mereka dapat membangun pikiran mereka sendiri dan melakukan segala sesuatu di luar standar mereka. Motivasi kerja merupakan salah satu faktor penting dalam menciptakan jiwa berwirausaha. Motivasi bisa datang dari diri sendiri dan juga dari orang lain. Munandar mengatakan bahwa motivasi kerja dari seseorang bisa lebih proaktif dan interaktif. Motivasi untuk pekerjaan proaktif orang akan mencoba mengembangkan kemampuan mereka seperti apa yang diminta.

Karyanya akan berusaha menemukan peluang yang didapatkan untuk menunjukkan pekerjaan yang tinggi. Di sisi lain, motivasi kerja dari orang yang suka membalas dendam lebih mungkin untuk menunggu dari upaya dan penawaran berdasarkan lingkungannya ketika dia bersedia bekerja jika dia didukung dan dituntut. Menurut Oemar Hamalik motivasi untuk memasuki pasar kerja merupakan suatu proses menentukan tingkat aktivitas, kekerasan, stabilitas dan arah umum perilaku manusia berdasarkan minat, sikap, dll. Setiap manusia memiliki perbedaan motivasi untuk memenuhi apa yang ingin Anda capai.

Narapidana adalah seseorang yang kehilangan hak kemerdekaannya. Tetapi narapidana juga memiliki hak yang sama dalam menerima pendidikan yang layak. Narapidana juga bisa berperan dalam pertumbuhan ekonomi baik itu di dalam lapas maupun setelah bebas dari lapas, dalam arti kalimat lengkap dihakimi Bagian dari warga negara Indonesia, meskipun telah melanggar hukum, tetap saja memiliki hak yang sama untuk menerima pendidikan yang layak dan berkualitas.

Dari pengamatan penulis, saya mendapatkan informasi bahwa karakteristik 
penghuni Penjara sangat beragam dalam hal usia, pendidikan, kehidupan beragama, ekonomi dan masyarakat serta berbicara. Dengan keragaman karakteristik ini, sebagai makhluk sosial, setiap orang harus mampu mengatasi semua masalah yang muncul sebagai akibat berinteraksi dengan lingkungan sosial dan mampu menampilkan diri sesuai dengan aturan dan norma yang Digunakan dalam masyarakat. Setiap orang harus memiliki keterampilan sosial serta kemampuan untuk beradaptasi dengan lingkungan yang ada disekitarnya. Keterampilan sosial dan adaptasi Cara yang lebih penting ketika seorang anak berada dalam masa remajanya, karena pada masa remajanya, seorang individu memasuki asosiasi teman yang lebih luas dan berpengaruh untuk menentukan pola perilaku.

Kegagalan seorang remaja untuk belajar keterampilan sosial akan membuatnya sulit untuk beradaptasi dengan lingkungan sekitarnya sehingga dapat menyebabkan perasaan memalukan, kehilangan hubungan, dan kecenderungan untuk bertindak melawan social. Remaja berubah dari masa kanak-kanak menjadi dewasa. Selama pada masa remaja pasti mengalami banyak perubahan, baik itu perubahan fisik ataupun perubahan mental. Perubahan fisik yang berubah dengan cepat untuk mencapai bentukan tubuh dari orang dewasa sambil mengembangkan kemampuan reproduksi. Selama masa ini, remaja mulai memisahkan emosi dari orang tua mereka dalam mengambil peran sosial baru sebagai orang dewasa.

Secara umum, remaja dibagi menjadi tiga bagian. Pertama-tama, remaja awal berusia 12 hingga 15 tahun, ketika seorang individu mulai keluar dari peran seorang anak dan mencoba mengembangkan dirinya sebagai individu yang unik dan tidak harus bergantung pada orang tua. Kedua, remaja berusia 15-18 tahun ditandai dengan perkembangan kemampuan berpikir baru. Teman masih memainkan peran penting bahkan jika orang itu lebih mandiri. Ketiga, remaja akhir 19 hingga 22 tahun ditandai dengan persiapan akhir untuk memasuki peran orang dewasa. Selama masa ini, individu remaja berusaha untuk menciptakan tujuan profesional dan mengembangkan rasa identitas pribadi dan keinginan kuat untuk tumbuh dan diterima oleh teman dan orang dewasa.

Kaum muda menghadapi kebutuhan, harapan, risiko, dan godaan yang semakin kompleks. Risiko paling umum untuk remaja termasuk penyalahgunaan narkoba, kenakalan remaja, kekerasan fisik dan pencurian identitas. Akibatnya, beberapa dari mereka harus mendekam di penjara untuk mempertanggungjawabkan tindakan mereka. Saat di penjara, tentu tidak mudah 
bagi mereka untuk bersosialisasi, terutama untuk mendapatkan kembali kepercayaan diri dalam persiapan ketika mereka kembali ke masyarakat. Salah satu ketentuan yang dimaksud dalam hal ini adalah pendidikan kewirausahaan yang mereka terima saat di penjara. Oleh karena itu, siswa (andik) di penjara ini perlu memiliki pelatihan dan pelatihan kewirausahaan berdasarkan minat, kemampuan dan keterampilan mereka. Upaya pemberdayaan wirausaha dalam bentuk edukasi diharapkan menjadi manusia yang mandiri.

\section{METODE PENELITIAN}

Penelitian ini menggunakan metode kuantitatif yang diterapkan dalam Program Pendidikan Operasional di Lapas kelas II B Kota Pariaman. Strategi penelitian kuantitatif yang digunakan adalah pengumpulan data disertai observasi dan wawancara.

Teknik pengumpulan data dengan literatur, observasi dan wawancara. Program yang diamati oleh peneliti adalah program pendidikan kewirausahaan dalam bentuk pelatihan keterampilan. Dalam studi kuantitatif ini, tidak perlu untuk pengambilan sampel atau pemilihan acak peserta dan lokasi penelitian. Pada saat yang sama, untuk mencari kepentingan narapidana di sektor bisnis, pengambilan sampel ini hanya didukung oleh data kuantitatif yang tersedia. untuk mendapatkan gambaran pendidikan kewirausahaan merupakan suatu frekuensi factor penting untuk menumbuhkan minat usaha narpiadana yang terdapat di lapas berdasarkan karakteristik berdasarkan usia, pendidikan, minat wirausaha, bentuk kejahatan, , analisis pendidikan kewirausahaan yang selama ini dilaksanakan, dan factor pendukung dan penghambat dalam kegiatan wirausaha pada narapidana di lembaga pemasyarakatan kelas IIB kota Pariaman.

\section{PEMBAHASAN}

Pembekalan terhadap pelatihan kewirausahaan di dalam lapas kelas IIB Pariaman sebenarnya sudah berjalan dan sudah mendapatkan hasilnya. Seperti pelatihan tentang bercocok tanam tanpa tanah atau biasa disebut hidroponik. Disini Kalapas langsung mendatangkan pelatih yang sudah profesional yang sudah lama berkecimpung didunia berkebun hidroponik. Pelatihan berlangsung secara berkala atau dua kali dalam satu minggu. Ketika sudah panen tumbuhan hidroponik dijual keluar yang tempat penjualannya sudah dicarikan oleh pelatih tersebut. Selain itu pelatihan lain yang sudah dilakukan adalah pengelasan. Tetapi dalam hal ini narapidana mengatakan masih banyaknya halangan dan kekurangan dalam pelatihan 
tersebut. Seperti kurangnya sarana dan prasarana, lahan yang tidak memadai, arus litrik yang kurang bagus dan masih banyak lagi. Sebenarnya narapidana mempunyai banyak ragam dalam hal pendidikan mulai dari tamatan sd sampai lulusan perguruan tinggi. Berdasarkan hasil penelitian, wawancara, dan teknik pengumpulan data yang lainnya yang dilakukan terhadap petugas lapas, narapidana di lapas IIB kota pariaman maka di dapatkan hasilnya sebagai berikut :

Tabel 1 Pendidikan

\begin{tabular}{|c|c|c|c|}
\hline NO & $\begin{array}{c}\text { PENDID } \\
\text { IK-AN }\end{array}$ & $\begin{array}{c}\text { JUMLA } \\
\text { H (N) }\end{array}$ & $\begin{array}{c}\text { PRESENTAS } \\
\text { E }(\%)\end{array}$ \\
\hline 1 & SD & 2 & $10 \%$ \\
\hline 2 & SMP & 5 & $25 \%$ \\
\hline 3 & SMA & 10 & $50 \%$ \\
\hline 4 & S1 & 3 & $15 \%$ \\
\hline \multicolumn{2}{|c|}{ Jumlah } & 20 & $100 \%$ \\
\hline
\end{tabular}

pendidikan dari responden yang mana tamat SD sebanyak 2 responden 10\%, 5 responden yang tamat SMP 25\%, 10 responden yang tamat SMA $50 \%$, dan 3 responden yang lulus S1 15\%.

Tabel 2 umur

\begin{tabular}{cccc}
\hline NO & \multirow{2}{*}{ UMUR } & $\begin{array}{c}\text { JUMLAH } \\
(\mathbf{N})\end{array}$ & $\begin{array}{c}\text { PRESENTASE } \\
(\boldsymbol{\%})\end{array}$ \\
\hline 1 & $20-40$ & 10 & $50 \%$ \\
2 & $>40$ & 10 & $50 \%$ \\
\hline
\end{tabular}

Tabel 2 menunjukan hasil umur yang ikut berpratisipasi atau disebut juga respond yang mana 10 responden berumur rentang 20-40 tahun $50 \%$, dan umur $>40$ memilki 10 responden $50 \%$.

Tabel 3 betuk kejahatan narapidana

\begin{tabular}{|c|c|c|c|}
\hline NO & BENTUK & $\begin{array}{l}\text { JUML } \\
\text { AH (N) }\end{array}$ & $\begin{array}{c}\text { PRESEN } \\
\text { TASE ( } \% \\
\text { ) }\end{array}$ \\
\hline 1 & NARKOBA & 10 & $50 \%$ \\
\hline 2 & $\begin{array}{c}\text { PERAMPOK } \\
\text { AN }\end{array}$ & 3 & $15 \%$ \\
\hline 3 & PENCURIAN & 4 & $20 \%$ \\
\hline 4 & $\begin{array}{c}\text { PENGANIA } \\
\text { YAAN }\end{array}$ & 2 & $10 \%$ \\
\hline 5 & PENIPUAN & 1 & $5 \%$ \\
\hline
\end{tabular}
responden tersebut yang mana $10(50 \%$ ) responen terjerat narkoba, 3 (15\%) responden kasus perampokan, 4 (20 \%) responden kasu pencurian, 2 (10\%) responde kasus penganiayaan, 1 (5\%) responden kasus penipuan.

Tabel 4 minat usaha

\begin{tabular}{|c|c|c|c|}
\hline NO & $\begin{array}{l}\text { MINAT } \\
\text { USAHA }\end{array}$ & $\begin{array}{c}\text { JUMLA } \\
\text { H (N) }\end{array}$ & $\begin{array}{c}\text { PRESENTAS } \\
\text { E }(\%)\end{array}$ \\
\hline 1 & $\begin{array}{c}\text { DAGAN } \\
\text { G }\end{array}$ & 10 & $50 \%$ \\
\hline 2 & JASA & 5 & $25 \%$ \\
\hline 3 & AGRIA & 5 & $25 \%$ \\
\hline 4 & $\begin{array}{c}\text { PROPER } \\
\text { TI }\end{array}$ & 0 & $0 \%$ \\
\hline
\end{tabular}
dari responden dagang terdapat 4 responden $50 \%$, jasa 5 responden $25 \%$, agria 5 responden $25 \%$, dan propeti 0 responden $0 \%$. 
Faktor Pendukung dan Faktor Penghambat Program pelatihan untuk menumbuhkan jiwa

Wirausaha Narapidana

Faktor pendukung

untuk meningkatkan perilaku kewirausahaan dilapas merupakan faktor untuk mendorong dan menumbuhkan jiwa wirausaha dalam diri narapidana. Beberapa faktor pendukung seperti pemproggaman narapidana, Kegiatan pembelajaran bisnis (Business operations) yang dapat dikembangkan, mengasah keahlian warga binan dalam membuka peluang bisnis, Bimker di Lapas harus memiliki instruktur / pelatih profesional yang memiliki sertifikat yang berkaitan dengan spesialisasi mereka. Ini dilengkapi dengan perintah "S". Pelatih:

"... faktor pendukung untuk proyek perilaku adalah adanya kegiatan pembelajaran kewirausahaan. Kemudian para pelatih adalah profesional karena mereka memiliki sertifikat sesuai dengan cabang mereka. Di sini kita menciptakan [Suasana keluarga, sehingga narapidana yang disponsori akan merasa nyaman dan memiliki interaksi yang baik. "

Selain faktor pendukung di atas, ada faktor pendukung lainnya. Termasuk hubungan baik antara pelatih dan narapidana.

Factor penghabat dalam melakukan pelatihan kewirausahaan menumbuhkan jiwa wirausaha narapidana, adapun beberapa factor penghambat Operator adalah alat yang terbatas, bahkan jika alat itu Tetap up to date, tetapi jumlahnya terbatas, keterbatasan alat membuat beberapa tujuan produksi mundur dari waktunya.

Faktor negatif lainnya adalah kebosanan narapidana yang masa pidananya sangat lama oleh karena itu Panjangnya pidana yang ditentukan Ini adalah hambatan Karena itu memengaruhi pelatihan narapidana, yakni Bosan karena malas menjalankan saran dari pelatih Seperti yang dibilang oleh "RR" sebagai narapidana:

"Selama saya bersama Bimker, kendala yang saya rasakan adalah alat yang terbatas, jadi kami digantikan oleh alat itu. Meskipun setiap napi memiliki tanggung jawab untuk menambah keterampilan. Tapi kadang-kadang saya bosan dengan situasi karena waktu di penjara yang kadang-kadang malas. "

Perhitungan menunjukkan bahwa responden tertarik pada perdagangan $50 \%$, sektor jasa $25 \%$, sektor pertanian $25 \%$. Menurut rekomendasi / ikhtisar pelatihan yang disajikan di atas, kegiatan paling populer adalah Berkebun. Beberapa tahanan yang kami wawancarai mengatakan mereka memilih berkebun karena lebih mudah dilakukan dan dapat dilakukan. Selain itu, 
diketahui bahwa sebagian besar tahanan kebun lebih tua dari 40, yang mengatakan mata mereka tidak lagi waspada ketika mereka harus meletakkan jarum ketika mereka harus melakukan kegiatan menjahit. Misalnya, di Jepang, keterampilannya cocok untuk kaum muda yang tidak bertani. Dengan bertani bisa memberikan ketenangan dan menghilangkan stress.

Sebagian besar kepentingan kewirausahaan ada di sektor perdagangan. Ini kemungkinan besar karena sebelum mereka berada di penjara, mereka berjuang di bidang yang sama dan mereka juga mendapatkan gambaran tentang manfaat menjadi pengusaha yang nantinya bisa mereka dapatkan. Pengusaha jika mereka memiliki keterampilan khusus Pelatihan keterampilan diperoleh saat di penjara.

Adapun hasil di bidang lain seperti jasa dan layanan pertanian, yang jauh lebih kecil, ini karena orientasi pengusaha melalui sektor perdagangan menghasilkan lebih cepat sementara cabang lainnya membutuhkan lebih banyak energi dan waktu. Faktor usia muda masih mempengaruhi daya juang mereka untuk bertahan hidup yang sangat kecil, karena inilah yang membuat mereka menginginkan semuanya cepat dan nyata.

Pelatihan adalah proses di mana serangkaian tindakan (upaya) sengaja dilakukan dalam bentuk bantuan untuk

tenaga kerja yang dilakukan oleh para ahli untuk pelatihan dalam satuan waktu yang bertujuan untuk meningkatkan kemampuan pekerjaan. Peserta dalam bidang kerja tertentu untuk meningkatkan efisiensi, pelatihan menurut Soekidjo Notoatmodjo (2009: 19) "adalah kegiatan untuk meningkatkan kemampuan karyawan atau karyawan dalam Jadi, pelatihan institusional adalah proses yang akan mengarah pada perubahan perilaku bagi karyawan atau staf. "

Penelitian yang relevan jelas menunjukkan bahwa ada pengaruh yang signifikan dengan pelatihan operator.

Perhatian pengusaha dapat dipicu oleh temuan warga LAPAS yang telah berpartisipasi dalam pelatihan kewirausahaan mereka, memperkuat keterampilan mereka untuk mempersiapkan bisnis untuk mengambil tindakan untuk menciptakan minat kewirausahaan Itu.

\section{Pengaruh}

\section{Kewirausahaan}

\section{berwirausaha.}

Ini konsisten dengan hasil dari wawancara petugas lapas dalam penelitian ini bahwa tujuan lapas untuk melatih wirausahawan adalah untuk mengatur mereka setelah meninggalkan lapas sehingga mereka dapat menerapkan pengetahuan pelatihan mereka Diterima 
Dari penjara, jangan ulangi tindakan sebelumnya.

Ini sejalan dengan komentar Valerio yang mengatakan bahwa pelatihan wirausaha merupakan suatu program dan berfokus pada pengembangan pengetahuan dan keterampilan untuk mempersiapkan memulai bisnis. Dalam program pelatihan ini Berpartisipasi dalam praktik.

Beberapa penelitian dengan jelas memperlihatkan bahwa ia memiliki pengaruh yang sangat signifikan terhadap pelatihan wirausaha.

Oleh karena itu, berdasarkan penelitian ini, penghuni lapas yang menghadiri pelatihan, wirausahawan melatih keterampilan mereka untuk mempersiapkan bisnis untuk dilanjutkan agar dapat membuat Tertarik menjadi wirausaha.

\section{Pengaruh Motivasi Kerja} Terhadap Minat Berwirausaha.

Konsisten dengan hasil wawancara dengan petugas lapas dalam penelitian ini, bahwa motivasi kerja untuk wirausahawan terlihat bagus. Kalimat dari narapidana menempatkan mereka dalam kelompok yang menerima keterampilan kewirausahaan untuk memotivasi pekerjaan mereka bersama dengan pengetahuan yang mereka terima. Ini berarti bahwa motivasi kerja mereka memiliki efek positif pada minat pengusaha. Ikuti komentar yang ditunjukkan oleh Munandar bahwa motivasi dari kerja seseorang mungkin lebih tanggap dan interaktif. Dalam motivasi untuk bekerja secara tanggap, orang tentu mencoba meningkatkan kemampuan mereka guna memenuhi persyaratan pekerjaan mereka, yang akan berusaha dalam menemukan serta menciptakan berbagai peluang bahwa mereka bisa menggunakan bakat mereka untuk menunjukkan pekerjaan yang lebih baik. Di sisi lain, motivasi kerja dari orang yang membalas dendam lebih mungkin untuk menunggu suatu upaya dan penawaran dari lingkungannya ketika dia bersedia bekerja apabila dia didukung dan dipaksa untuk bekerja.

Ini menunjukkan bahwa insentif kewirausahaan memiliki efek positif pada minat kewirausahaan. Yang berarti bahwa semakin termotivasi bisnis ini, semakin banyak Ketertarikan pada wirausaha juga tinggi.

Pengaruh Pelatin Kewirausahaan dan Motivasi Kerja Terhadap Minat Berwirausaha .

Wawancara yang pernah dilakukan dengan petugas lapas dalam penelitian ini mengungkapkan bahwa keberadaan pelatihan wirausaha yang sedang dilakukan di lingkungan lapas memiliki efek positif pada kepentingan mereka yang Beroperasi Demikian juga, insentif kerja yang 
narapidana merasa bahwa mereka telah memperoleh keterampilan dalam pelatihan kewirausahaan adalah arahan penting antara motivasi kerja dan minat wirausaha pada penghuni lapas. Sesuai dengan komentar Suryana yang mengatakan bahwa minat berwirausaha merupakan tren jantung untuk fokus membangun bisnis yang terorganisir, terorganisir, membawa risiko serta mengembangkan bisnis yang telah diciptakannya. Meningkatnya minat pengusaha dapat menemukan potensi yang ada pada individu. Ini memperlihatkan bahwa insentif kewirausahaan memiliki efek positif pada minat kewirausahaan. Yang berarti bahwa semakin Anda termotivasi dalam karir Anda, semakin banyak minat Anda dalam pekerjaan. Penelitian ini sejalan dengan penelitian.

Hasil positif yang dapat dipromosikan oleh pelatihan wirausaha tertarik menjadi wirausahawan dan mampu membangun bisnis mereka sendiri serta dapat menciptakan lapangan kerja untuk orang lain. Beberapa penelitian telah menunjukkan bahwa terdapat pengaruh positif antara pelatihan wirausaha dengan motivasi kerja terhadap minat wirausaha.

Factor medukung dan penghambat dalam melakukan pelatihan wirausaha dalam menumbuhkan jiwa wirausahawan bagi narapidana yang berada di dalam lapas:
Dari hasil penelitian dapat diketahui faktor-faktornya mendukung dalam pelatihan wirausaha dalam upaya membentuk perilaku kewirausahaan di lapas dapat digambarkan sebagai berikut:

- Terdapatnya Kegiatan Belajar Usaha

Kegiatan belajar wirausaha adalah kegiatan yang menciptakan sikap Pengusaha terintegrasi dengan pelatihan keterampilan dari Kegiatan-kegiatan yang menumbuhkan warga dapat belajar tentang sikap pengusaha seperti Mampu mengkomunikasikan tanggung jawab untuk mengelola dana yang diterima dari studi ini berdasarkan teori perilaku wirausaha bahwa segala sesuatu harus ditanggapi dengan serius dan bertanggung jawab (Kasmir, 2011: 32).

- Pelatih yang memiliki keahlian dalam bidangnya

Pelatih profesional di miliki Keluarga Bimker adalah salah satu faktor pendukung Implementasi Pelatihan Keterampilan di lapas, sebelum menjadi pelatih atau pelatih Hadiri pelatihan serta cabang pendukung Ada sertifikat untuk tujuan mempromosikan narapidana, yaitu Tahanan berhasil mendapatkan pengetahuan keterampilan yang paling sedikit Untuk dapat hidup mandiri dan berpartisipasi dalam berbagai kegiatan Pembangunan nasional (Kementerian Hukum dan Hak 
Asasi Manusia Republik Indonesia) Untuk mencapai tujuan pelatihan, perlu Miliki pelatih atau instruktur yang ahli dalam bidangnya Ini Merupakan faktor pendukung dalam menerapkan pengembangan keterampilan Mencapai tujuan pelatihan mandiri.

Selain factor pendukung yang telah di teliti tentu juga terdapat faktor penghambat terdapt juga hasil telitinya, sebagi berikut:

\section{- Kebosanan narapidana}

Pidana yang sangat lama yang di dapatkan oleh narapidana dapat Pengaruh pelatihan menggunakan Mendorong orang dengan rasa kebosanan membuat orang bosan dan bosan Malas mengikuti tutorial Perilaku dipengaruhi oleh kondisi Interaksi lingkungan dan interpersonal (Walgito, 2003) dari teori Dapat disimpulkan bahwa kondisi seseorang atau masyarakat Dapat mempengaruhi sikap seseorang berdasarkan kondisi dan rutinitas Utuh dan untuk waktu yang lama akan membuat orang itu menunjukan perilaku malasnya.

\section{- Jumlah alat yang sangat terbatas}

Alat yang dibatasi mencegah orangorang target untuk bergabung Pedoman untuk tidak dapat menemukan produk target pada waktu yang ditentukan dalam produksi produk untuk tujuan pemasaran. Menurut teori tersebut, alat yang digunakan oleh orang yang dilindungi adalah modern tetapi terbatas, sehingga pelindung harus bergiliran sementara proses produksinya tidak sama, sehingga menghambat proses produksi. Pengadaan fasilitas dalam bentuk peralatan modern yang terbatas dapat menghambat proses produksi, yang membuatnya tidak mungkin untuk mencapai tujuan produksi, yang terkait dengan sikap operator dari produk target.

\section{KESIMPULAN}

Hasil penelitian memiliki pengaruh yang signifikan selama pelatihan kewirausahaan pada minat wirausaha dan arah hubungan positif. Ini berarti bahwa dengan adanya pelatihan kewirausahaan, minat kewirausahaan di penghuni lapas meningkatkan dampak pada pelatihan operator yang dilakukan oleh penjara. Ada beberapa pengaruh yang sangat signifikan diantara motivasi kerja terhadap suatu minat wirausaha dan arah hubungan positif. Ini berarti bahwa ada peningkatan motivasi kerja oleh penghuni lapas terhadap kepentingan operator penghuni lapas.

Ada pengaruh yang sangat signifikan diantara pelatihan wirausaha dengan motivasi kerja tentang minat wirausaha. Ini menunjukkan bahwa pengusaha tertarik pada pelatihan kewirausahaan di lapas dan motivasi kerja. Pelatihan wirausaha yang ditingkatkan dan insentif kerja yang diselenggarakan oleh lapas, minat wirausaha akan meningkat dan sebaliknya. 
Dan terdapatnya faktor pendukung maupun faktor penghambatnya, seperti faktor pendukung yaitu terdapatnya giat belajar seperti kekeluargaan dan pelatih yang memiliki skill yang kompeten di bidangnya masing masing, sedangkan faktor penghambatnya yaitu terdapatnya alat yang belum memadai / sarana dan prasran dan rasa bosan dari narapidana itu sendiri.

\section{DAFTAR PUSTAKA}

\section{a. Book:}

Hendro. (2014). Dasar - Dasar

Kewirausahaan. Jakarta: Erlangga.

Basrowi. (2014). Kewirausahaan Untuk Perguruan Tinggi. Bogor: Ghalia Indonesia

Iyo Mulyono. (2011). Dari Karya Tulis Ilmiah sampai dengan Soft Skills. Bandung: Yrama Widya.

Fahmi, Irham. (2016). Kewirausahaan Teori, Kasus dan Solusi. Bandung: Alfabeta.

Suryana. (2013). Kewirausahaan Kiat dan Proses Menuju Sukses Edisi Empat. Jakarta: Salemba Empat.

\section{b. Journal:}

Aprilianty,Eka.(2012). Pengaruh Kepribadian Wirausaha Pengetahuan Kewirausahaan dan Lingkungan Terhadap Minat Berwirausaha Siswa SMK. Jurnal Pendidikan Vokasi 2 (3); 311-32.

Suhermini. (2010). Menumbuhkan Minat Kewirausahaan Melalui Perbuatan Bisiness Plan. Jurnal Pendidikan Ekonomi Dinamika Pendidikan 5(2); 180-196.

Mahesa, Aditya Dion. (2012). Analisis Faktor-Faktor Motivasi Yang Mempengaruhi Minat Berwirausaha. Diponegoro Jounal Of Management 1(1); 130-137.

Melyana,I.P., Rusdarti dan Amin, P. (2015). Pengaruh Sikap dan Pengetahuan Kewirausahaan terhadap kesiapan Berwirausaha melalui Self-Efficacy (Versi Elektronik). Journal of Economic Education 4(1); 8-13.

\section{c. Internet}

Alfi yuda (2021). Pengertian wirausaha, tujuan, kelebihan, kekurangan, ciriciri, dan contohnya yang perlu diketahui. Diakses tanggal 28 Juli 
2021

dari

https://www.bola.com/ragam/read/4

616934/pengertian-wirausaha-

tujuan-kelebihan-kekurangan-ciri-

ciri-dan-contohnya-yang-perlu-

diketahui

Kompas (2021). Jumlah pengangguran di indonesia turun jadi 9,1 juta orang.

Diakses tanggal 5 November 2021

dari

https://money.kompas.com/read/202

$\underline{1 / 11 / 05 / 211102226 / j u m l a h-}$

pengangguran-di-indonesia-turun-

jadi-91-juta-orang?page $=$ all

Kementerian keuangan (2021). Pemerintah perkuat UMKM melalui berbagai bentuk bantuan. Diakses tanggal 27 September $2021 \quad$ dari https://www.kemenkeu.go.id/publik asi/berita/pemerintah-terus-perkuatumkm-melalui-berbagai-bentukbantuan/ 